\title{
Influence of Employee Performance Contracting on Organization Performance in Kapenguria County Referral Hospital Kenya
}

\author{
Kapusien Y. Luke and Erastus Thoronjo
}

\section{ABSTRACT}

Performance contracting is a strategic technique that uses feedback loops to meet desirable targets. Introduction of performance contracting by the government was seen as effective and hopeful method for improvement of the performance in public institutions and state agencies. Past Studies on Performance contracting, and Organization performance shows that there had never been a study on how Performance Contracting influences performance of County Referral Hospitals and there lay the research gap. The research main objective was to ascertain the effect of performance contracting results on organizations performance in Kapenguria County Referral Hospital. In a specific way, the study sought to find out how performance contract target setting influence performance of the Hospital. The target population was 291 employees of Kapenguria County Referral Hospital, the study used a stratified random sampling technique to get the sample size which was 184 employees. Descriptive research design was adopted by this study. The study utilized primary data mainly collected using structured questionnaires. The data collected was then analyzed using descriptive and inferential statistics with the help of SPSS. Tables were used to present the results of the study. The study found out that there was a positive and significant relationship between Target setting and Organization performance, this, therefore, implied that setting of targets in performance contracting influenced the organizational performance. results of ANOVA established that there was a significant mean because the coefficients were all less than 0.05 . lastly, all independent variables had statistically significant association with the dependent variable at $95 \%$ level of confidence. The study, therefore, concludes that performance contracting greatly influence organization performance. Going by high affirmation of the respondents, Performance contracting enhances assertion of more effort by employees to their duties and tasks, motivates employees when rewarded or recognized based on the results of evaluation, enhances work accountability in the organization among others. this study recommends that there should be adequate consultation and involvement of employees in setting of targets, this will lead to high employees' commitment to the set targets and in turn enhance achievement of the general organizational targets.

Keywords: Kapenguria County Referral Hospital, Organization performance, Performance Contracting.
Submitted : October 20, 2021

Published : November 112021

ISSN: 2507-1076

DOI: $10.24018 /$ ejbmr.2021.6.6.1146

\section{Kapusien Y. Luke}

School of Business and Economics, Mount Kenya University, Kenya.

(e-mail: lukeyego@gmail.com)

Erastus Thoronjo

$\mathrm{PhD}$, School of Business and Economics, Mount Kenya University, Kenya.

(e-mail: ethoronjo@gmail.com)

\section{INTRODUCTION}

Globally, the idea of PC has been embraced in Europe, Latin America, Asia, and Africa. This concept originated in France in 1960's after the publication of a report on the reorganization of state-owned enterprises by Simon Nora with primary objective of reducing the government budgetary support to public enterprises (Nganyi, Shigogodi, \& Owamo 2014). In France, it is called a contract plan whereby agreement between government-owned enterprises based on a five-year job plan is developed. Later its use spread to Pakistan, Korea, India as well as various parts of the world as an effective system of addressing challenges of improving service delivery to the public (Obong'o, 2009).
In many African countries, the end of colonialism introduced enormous development of public service, experience of low outcomes in government organisations called for a new comprehensive reform plan for the public sector to address the problems. Many African countries have started managing public services through the implementation of PCs since 20052005 (Cheche \& Muathe 2014). According to Ndung'u (2009), Leaders used employment in the government service to reward chronicles for allegiance and to ensure that vital services were not left in foreigners' hands (Mutahaba, 2011). This scenario resulted in a ballooning of GDP-related salary bills that caused governments to lend to satisfy operating costs from multi-lateral lenders. Governments' failure to satisfy 
operating expenses that led to multilateral donors' borrowing was the cause for reforms in the public service, as lenders precisely the World Bank and the International Monetary Fund compelled most governments under the Structural Adjustment reforming their civil sector policy (Mutahaba, 2011).

Performance Contracting was implemented in Kenya's public service for the first time in 2004 through the 1991 authorized Parastatal Reform Strategy Paper, as part of the Civil Service Reform mandated under the Economic Recovery Strategy for the Creation of Wealth and Employment (ERS) (GoK, 2010). According to Gakure, et al. (2013), the anticipated results of the implementation of PCs include enhancement of service provision, the institutionalization of a success-oriented culture in public service, enhancement of resource efficiency, performance measurement and assessment and enhancement of general government institutions performance.

\section{A. Statement of the Problem}

There are increasing concerns in Kenya on the low quality of health care services delivered by public sector organizations. The poor quality of service in public hospitals in Kenya is evident in the rate of strikes that take place in public healthcare institutions across the country. This is supported by the existence of numerous private clinics and hospitals even some that are not licensed mushrooming in unlikely places, and able to access customers who otherwise would have been better served by the public hospitals. Thus, improvement of organizational performance in the public health sector is an urgent problem (Muthui 2018).

This area of Performance contracting, and Organization performance has received significant studies, for instance; Diallo (2017) conducted research on the determinants of employee performance contracts on the Senegalese public media sector. from the study, Diallo found out that PC contributed to improved morale of workers. Uusikyla and Virtanen (2009) studied Performance Contracting in government of Finland. The findings showed that PC was critical in re-focusing the public servants to be more result oriented, Letangule and Letting (2012) examined the Influence of performance contracts on the institutional performance of Kenya's education ministry, they found that setting rational and measurable goals in the process of performance contracting contributes significantly to improving government entity performance. Makewa and Were (2017) did a study on PC impact on public universities success in Kenya, they found out that setting of targets contributed to Organizational Performance in Public Universities. Kitsao (2018) did a study on PC, performance of Ministry of Transport in Kenya, the finding of the study indicated that effectiveness of Performance contracting used by government, and private entities rely on employees understanding of PC.

These Studies on Performance contracting, and Organization performance shows that there has never been a study on how Performance Contracting influence performance of County Referral Hospitals and there lied the research gap. Considering this principle, the research, therefore, sought to establish the impact of employee performance contracting on organizational performance in Kapenguria County Referral Hospital.

\section{B. Objective of the Study}

To establish the influence of Target Setting on Organization performance in Kapenguria County Referral Hospital.

\section{TheORETICAL ReVIEW: GoAl SetTing THEORY}

This theory is established on the assumption that much human action is deliberate as it is guided by conscious objectives and desires. The proponents of this theory Locke and Latham (2006) clarified in-depth that workers were inspired by particular and challenging goals and fitting feedback on their performance. Setting a goal involves establishing levels of performance that direct people's actions and behaviors which improves the unsatisfactory performance. That is; the willingness and intention to realize the set objectives is the source of motivation. This helps people and organizations to achieve greater and better job efficiency. Furthermore, feedback offers possibilities to clarify aspirations and adjust goal challenges and achieve recognition (Locke \& Latham,2006).

In this context, there are two primary insights: specificity of the objective and complexity of the objective. Later studies have indicated that challenging objectives can lead to higher employee effort and determination if well accepted by organizational employees (Newstrom, 2011). The fundamental assumption of Locke is that the deliberate intentions of a person control their behavior, and an objective is merely what the person tries to achieve. Thus, innovative goal result in a greater level of performance than simple objectives, and particular, aggressive objectives lead in a greater performance level than no objectives or a widespread goal of "doing your best" (Yukl \& Latham, 1978).

The significance of goal difficulty is supported by a substantial body of studies. Challenging goal is how difficult a goal is and needs effort. But a goal mustn't be so hard that it's impossible to achieve. If individuals work to attain objectives, it is sensible to believe that they will work harder to accomplish more challenging objectives and better incentives would be more realistic. (Luthans, 2011). An individual who is commended for reaching a hard objective will be encouraged to pursue the next challenging objective than someone who has not been rewarded for reaching the first objective. Active involvement in the setting of goals increases team efficiency by increasing the significance of goals for each team member and thus improving the dedication of goals (Newstrom, 2011).

Employees will normally accept goals when they actively participated in creating them. Inclusion of individuals in setting their goals is therefore vital. Feedback is another important factor for effective goal setting program. Feedback provides ways of clarifying expectations, difficult encountered and gain recognition. In addition to feedback, task complexity is also an important factor in goal setting theory. Special measures should be taken to make sure that the workload is not immense for these highly complex tasks. Goal theory is thus critical in execution of performance 
contract because without which productivity will not be achieved (Julnes et al. 2007).

Goals are more efficient when a time limit is included and is used for performance evaluation. Deadlines act as component for time control and boost inspirational effect of objectives. Being conscious of the nearing deadline, the typical person will make a concerted effort to complete the assignment. On the other side, when staff understand that their performance will indeed be assessed in terms of how well they have achieved their objectives, the effect of the objectives will rise (Borgogni \& Russo 2012).

Performance Contracting is based on goal theory principles in that the goals are SMART in nature, thus providing flexibility to the staff. The objectives are gradual, therefore difficulty and the involvedness of attaining them is increased every cycle of the PC resulting to enhanced employee performance and output. Staffs are given frequent response on their achievement using the quarterly evaluation of performance statements and in the extensive annual assessment at the end of the duration of the contract. The feedback allows staff to evaluate themselves and modify their actions and attempt to achieve the goals. Staff members are involved in the performance contract target environment and negotiations with their managers on the performance and accomplishment of the objectives (Nganyi et al., 2014).

\section{A. Literature Review: Setting of Targets and organization performance}

The strategic plan is the foundation of the performance contract. It is necessary to connect the strategic goal in the strategic plan to the government policies that are laid out from moment to moment. Such strategies include the Kenyan Vision 2030 and the National Development Plan. Targets are laid out from the strategic plan goals and mission. They should be thorough, growth-oriented, applicable, and based on previous trends and results of appropriate industry organizations locally and abroad (Mauya, 2015). Obong'o (2009) acknowledged that the organizations performance objectives are identified after the budget process and the organisations are notified of their distribution of resources. This guarantees that the goals set within the accessible funds are realistic and achievable. The objectives should be issued by the organizations, freely mediated and not arbitrarily enforced by the government.

Study by Omondi (2015) on effects of PC noted that the employees who are referred to as the appraisee are supplied with forms of appraisal at the beginning of the review period, in most cases at the commencement of financial year. The appraisee is expected to draw individual work plan and performance targets which will be the basis of performance reports. The main reason for appraising employees is to expansively and critical assess officer's performance in the job, with the help of full knowledge and understanding of the job descriptions and requirements (Gekonde, Ochieng \& Lokapel, 2013). Information in the evaluation report is used to evaluate the training requirements and examine the promotion possibilities of the employees. The assessment of employees represents the production of job and displays skills during review period (Mbuthia, Ngari \& Mwangi 2012).
Target setting is a very helpful way to improve the efficiency of employees. Target is a desirable goal from a motivational view. Most organisations use targets to provide a helpful structure for managing motivation (Ngetich 2013). Supervisors and staff can set their own goals and then work towards them. By setting objectives for them, the manager is going to impact people's conduct in the organisation. In view of this assumption, the primary task is to create a thorough knowledge of the procedures by which individuals set particular, hard but achievable goals and then work towards them (Newstrom, 2011).

Simply allocating targets to organizational employees may not lead to their dedication to those goals, particularly if the goals are hard to accomplish. An efficient technique of achieving target recognition is to enable employees of the organisation to engage in target setting (Kubaison, 2014). In other words, target-setting involvement tends to improve engagement objectives. Involvement enables employees of the organisation know the goal better, guarantee that the goals are rational and assist them to attain the goals (GoK, 2013).

For most staff, targets are more efficient if they take account of an accomplishment date. Deadlines serve as a component for controlling and increasing target motivational effect. Being conscious of the approaching deadline, a worker will put more effort into completing the assignment. Nevertheless, deadlines must not be too tight, especially with complicated assignments as the quality of job may be affected. Conversely, if there is still plenty of time to achieve a goal, the staff member is likely to slow the pace to fill the time available (DuBrin, 2012). In an organization and leadership practice, targets have a widespread impact on employee performance and behavior as acknowledged by Kinanga and Partoip (2013). Nearly every organisation is in operation with some sort of target environment. Target setting can be a strong method for motivating an organization's employees under the correct circumstances (Greenberg, 2011).

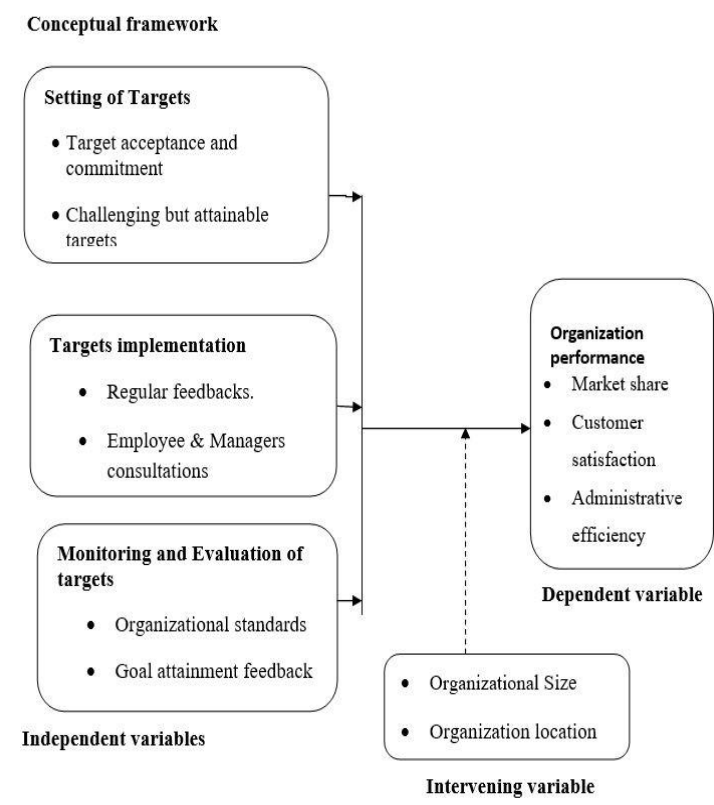

Fig. 1: Conceptual framework. Source: Researcher 2021. 


\section{RESEARCH METHODOLOGY AND DESIGN}

Descriptive research design was adopted by this study because this research design depicts precise description of individuals, occurrences or circumstances and enables extremely economical compilation of big quantities of information from a large population.

\section{A. Target Population}

The target population consisted of all the 291 employees of Kapenguria County Referral Hospital. The study population was stratified into two strata: Medical staff and Non-Medical staff. Medical staff comprised of all 264 employees in medical departments in the hospital while Non-Medical staff comprised of 27 employees is Admi.

\begin{tabular}{ccc}
\multicolumn{3}{c}{ TABLE I: TARGET POPULATION } \\
\hline Category & Population & Percentage $\%$ \\
\hline Medical staff & 264 & 90.72 \\
Non-Medical Staff & 27 & 9.28 \\
TOTAL & 291 & 100 \\
\hline
\end{tabular}

Source, Researcher 2021.

\section{B. Sampling Procedure, Techniques and Sample Size}

To ensure that every stratum was adequately represented, random sampling was carried out in each stratum. Slovin's formula was used to get sample size for each stratum and a margin error $\boldsymbol{e}$ of 0.05 based on $95 \%$ confidence level was applied. The sample size was 184 employees of Kapenguria County Referral Hospital:

$$
n=\frac{N}{1+N(e)^{2}}
$$

where

$n$ - sample size;

$N$ - total population of the study;

$e$ - margin error.

TABLE II: SAMPLE SIZE

\begin{tabular}{cccc}
\hline \multicolumn{4}{c}{ TABLE II: SAMPLE SIZE } \\
\hline Category & Population & $\begin{array}{c}\text { Sample } \\
\text { Size }\end{array}$ & Percentage \% \\
\hline Medical staff & 264 & 159 & 86.41 \\
Non-Medical Staff & 27 & 25 & 13.59 \\
TOTAL & 291 & 184 & 100 \\
\hline
\end{tabular}

Source, Researcher 2021.

\section{Data Collection Instruments and Analysis}

This study utilized primary data collected using closedended questionnaires where 5 point Likert scale applied. Likert scales are good because they show the strength of the people's feelings to whatever is in the questions, they are easy to collect data, they are easy to analyze, and they are more expansive. The research instruments were subjected to a pilot test to ensure content reliability and validity. This study's pilot test was conducted with $10 \%$ of the total sample population. The questionnaires were given to 29 employees who were chosen at random from various departments and levels of personnel. For consistency and completeness, the filled and returned questionnaires were filtered. Using descriptive statistics analysis software SPSS, quantitative data gathered were evaluated and displayed through percentages and frequencies. This research examined the impact of employee performance contracting on organizational performance at Kapenguria County Referral Hospital. The researcher, therefore, intended to determine how Organization performance as a dependent variable is influenced by employee performance contracting target setting. Multiple regression analysis was used to establish the degree of relations between the study variable.

\section{RESEARCH FINDINGS AND DISCUSSION}

\section{A. Response Rate}

A total of 184 questionnaires were issued out. Out of the 184 questionnaires used in the sample, only 149 questionnaires were filled and returned. The returned questionnaires represented a response rate of $80.98 \%$, which the study considered adequate for analysis.

\section{B. Respondents Profile}

Nurses were the majority of the respondents contributing $69.1 \%$ of the total respondents. Clinical officers and Doctors contributed $8.7 \%$ and $6 \%$ respectively. The rest of the respondents contributed between $0.7 \%$ and $2.7 \%$. Those in the age between 31 and 40 years were the majority representing $38.3 \%$ of the total respondents. those who had worked in the hospital between 1-5 years were the majority representing $38.9 \%$. The study sought to establish the respondent's highest education level; it was established that majority had attained Diploma as their highest level of education representing $60.4 \%$.

\section{Descriptive Statistics: Target Setting and Organization performance}

The study sought to determine the impact of target setting on organizational performance.

\begin{tabular}{|c|c|c|}
\hline Statement & Mean & Std. Dev \\
\hline $\begin{array}{l}\text { Setting of specific and challenging but } \\
\text { attainable targets lead to employees asserting } \\
\text { higher effort on their assigned duties. }\end{array}$ & 4.40 & 0.687 \\
\hline $\begin{array}{l}\text { Provision of flexible structure by top } \\
\text { management in the organization for } \\
\text { discussion during setting of performance } \\
\text { contracting targets lead to high productivity. }\end{array}$ & 4.14 & 1.027 \\
\hline $\begin{array}{l}\text { Adequate consultation and involvement of } \\
\text { employees in setting targets lead to } \\
\text { employees' commitment to the set targets } \\
\text { and thus enhance achievement of the } \\
\text { organizational targets. }\end{array}$ & 4.34 & 1.082 \\
\hline $\begin{array}{l}\text { Setting targets that are accompanied by } \\
\text { deadlines are achieved than those which are } \\
\text { not time-controlled. }\end{array}$ & 4.01 & 0.883 \\
\hline $\begin{array}{l}\text { The supervisors help ensure that employees } \\
\text { set targets that are verifiable. }\end{array}$ & 4.06 & 0.981 \\
\hline $\begin{array}{l}\text { The Hospital performance contract aims to } \\
\text { avoid target setting just for the sake of it but } \\
\text { with a realistic idea of the general } \\
\text { organizational goal. }\end{array}$ & 4.21 & 1.078 \\
\hline
\end{tabular}

The majority of respondents agreed (mean over 3.6) to all of the claims about the impact of target setting on organizational performance, according to the study's findings, the respondents agreed the most that Setting of specific and challenging but attainable targets lead to employees asserting higher effort on their assigned duties 
$($ Mean $=4.4 ;$ Std Dev $=0.687)$. On the other side, they least agreed that Setting targets that are accompanied by deadlines are achieved than those which are not timecontrolled $($ Mean $=4.01$; Std Dev $=0.883)$.

The purpose of the study was to establish how target setting affected the hospital's performance. According to the data, target setting, and organizational performance have a favorable and significant link, this, therefore, implies that the setting of targets in performance contracting influence the organizational performance. This is also evident by respondents agreeing to all the statements on target setting. They highly agreed that; Setting specific and challenging but attainable targets lead to employees asserting higher effort on their assigned duties. On the other side, they at least agreed that Setting targets that are accompanied by deadlines are achieved than those which are not timecontrolled. This study, therefore, is in concurrence with the results of a study by Letangule and Letting (2012) who examined the Influence of performance contracts on the institutional performance of Kenya's education ministry, they found that setting rational and measurable goals in the process of performance contracting contributes significantly to improving government entity performance.

\section{Inferential Statistics}

inferential statistics for the study were conducted which entailed correlation and regression analysis. This was aimed at determining the association between performance contracting and Organization performance.

\section{E. Regression Analysis}

At a 5\% level of significance, multiple regression analysis was used to assess the relationship between the independent and dependent variables. From the findings of the regression analysis, Target settings had 0.000 , Therefore, Target setting was more significant.

\begin{tabular}{|c|c|c|c|c|c|}
\hline \multirow[t]{2}{*}{ Model } & \multicolumn{2}{|c|}{$\begin{array}{l}\text { Unstandardized } \\
\text { Coefficients }\end{array}$} & \multirow{2}{*}{$\begin{array}{c}\text { Standardized } \\
\text { Coefficients } \\
\text { Beta } \\
\end{array}$} & \multirow[t]{2}{*}{$\mathrm{t}$} & \multirow[t]{2}{*}{ Sig. } \\
\hline & $\mathrm{B}$ & Std. Error & & & \\
\hline (Constant) & 4.701 & 0.318 & & 2.203 & 0.029 \\
\hline Target setting & 0.342 & 0.084 & 0.336 & 4.054 & 0.000 \\
\hline $\begin{array}{c}\text { Target } \\
\text { Implementation }\end{array}$ & 0.160 & 0.086 & 0.163 & 1.855 & 0.066 \\
\hline $\begin{array}{l}\text { Monitoring and } \\
\text { Evaluation }\end{array}$ & 0.318 & 0.087 & 0.290 & 3.639 & 0.000 \\
\hline
\end{tabular}

a. Dependent Variable: Organization Performance.

Source, Researcher 2021.

\section{F. Analysis of Variance}

The goal of this study was to determine the importance of the regression model in predicting the connection between independent and dependent variables using the Analysis of Variance. From the results of ANOVA, because the $p>$ value of 0.001 is less than the conventional $\mathrm{p}>$ value of 0.05 , the $\mathrm{F}$ >value of 38.319 and $\mathrm{p}>$ value of 0.001 it implied that the model was significant at $95 \%$ confidence level to predict the relationship between the independent variable; target setting and the dependent variable; Organization performance.
TABLE V: ANALYSIS OF VARIANCE (ANOVA)

\begin{tabular}{cccccc}
\hline Model & Sum of Squares & df & Mean Square & F & Sig. \\
\hline Regression & 28.730 & 3 & 9.577 & 38.319 & $0.000^{\mathrm{b}}$ \\
Residual & 35.239 & 141 & 0.250 & & \\
Total & 63.969 & 144 & & & \\
\hline
\end{tabular}

a. Dependent Variable: Organization Performance.

b. Predictors: (Constant), Target Setting, Target Implementation, Monitoring \& Evaluation.

Source, Researcher 2021.

\section{CONCLUSION}

The study premises that the tenets of employee performance contracting are Target setting, Target Implementation and Monitoring \& Evaluation. Influence of each of these tenets on employee performance greatly influence the general organization performance. From the inferential statistics, it was observed that there was a positive correlation between each independent variable and organization performance with Target Setting having the strongest correlation, result of ANOVA established that there was a significant mean because the coefficients were all less than 0.05, lastly, all independent variables had statistically significant association with the dependent variable at $95 \%$ level of confidence.

Based on these, the study concludes that employee performance contracting target setting greatly influence performance of the Kapenguria County referral hospital. Going by the highest level of respondent's agreement, setting of targets; encourage employee-supervisor consultation, employee asserting more effort to their duties and tasks which in turn lead to high productivity in the hospital.

\section{A. Recommendations}

Involvement of the employee in making a decision towards achieving performance contracting goals lead to higher performance, therefore, this study recommends that there should be adequate consultation and involvement of employees in setting targets, this will lead to employees' commitment to the set targets and enhance the achievement of the organizational targets. Also, the study recommends that Employees be allowed to express their dissatisfaction with the performance evaluation results and given chance to improve in case of poor performance.

The Hospital Management needs to invest in training of employees, both professional and skill-based training. This will help employees understand what needs to be done to improve the organization performance. They should be given all the skills and resources necessary to be able to accomplish their own objectives as well as the overall organization objectives towards improving both personal and organization performance.

Introduction of Performance contracting by the government was seen as an effective and hopeful method for improvement of the performance in public institutions, therefore, this study recommends that the National Government and the County Government should ensure that there are adequate resources in the Hospital if performance contracting is to improve the performance of the Hospital. These resources range from human resource to medicine supply as well as working areas and facilities. 
This study mainly focused on the influence of performance contracting in Kapenguria County Referral Hospital, therefore, another study needs to be carried in a different institution to find out if similar results will be achieved and especially in a hospital. Also, since this study focused on the general organization performance, a study on how performance contracting has improved service quality and satisfaction of patients in the Hospital can be carried out.

\section{REFERENCES}

Borgogni, L., \& Russo, S. D. (2013). A quantitative analysis of the high performance cycle in Italy. In E. A. Locke \& G. P. Latham (Eds.), New developments in goal setting and task performance (pp. 270-283). Routledge/Taylor \& Francis Group.

Cheche, S. (2014). A Critical Review of Literature Review on Performance Contracting. Global Journal of Trade and Administration. 3(6):65-70.

Diallo, O. (2017) Performance Contracting Effects on Employee's Motivation in the Senegalese Public Media Sector, American Journal of Research, Technology, and Science. 32, 132-148.

DuBrin, A. J. (2012). Essentials of Management. Mason, OH: Cengage South-Western.

Gakure, Eliud \& Karanja. (2013). Role of Performance Contracting in Enhancing Effectiveness of Performance in the Civil Service in Kenya, State Department of Infrastructure, Jomo Kenyatta University of Science and Technology (JKUAT), Kenya.

Gakure, R.W., Muriu, S. M.\& Orwa, G. (2013). Role of Performance Contracting in Enhancing Effectiveness of Performance in the Civil Service in Kenya, State Department of Information. Business and Marketing Journal, 14(6), (Nov. - Dec. 2013), 73-82.

Gekonde, T., Ochieng, P. \& Lokapel, E. (2013). Performance Contract Impact on Public Service Delivery in Kenya: Review of Persons Registration in Kericho. International Journal of Humanities and Social Science, 3, 1-7.

GOK, (2010). Evaluation of the Results for Kenyans Programme: Institute of Public Administration of Canada and the African Developmen Professional Group, Nairobi, Kenya: UNDP.

GOK, (2013). Results for Kenyans: Capacity Building Programme for Transforming the Public Service, Public Service Reform and Development Secretariat.

Greenberg, J. (2011). Behavior in organisations. Upper Saddle River, NJ: Prentice Hall.

Julnes P., Berry S. F., Aristigueta M. P., \& Yang, K. (2007). Promoting the Utilisation of Performance Measures in Public Organisations. International Handbook of Practice-Based Performance Management. 61(6).

Kinanga, R.O. \& Partoip, S.K. (2013). Linkage between target setting in performance contracting and employee performance: A view on Kenya. Journal of Research on Human Resources Administration.

Kitsao s. Loice (2018), Performance Contracting and Perfromance of Parastatals in The Minisrty of Transport, Kenya.

Kubaison, S. (2014). The Mediating Role of Employee Attitude on Participation-Performance Relationship in State owned Corporation in Kenya. International Journal of Research in Social Sciences.

Letangule, S. L, \& Letting, N. K. (2012). Effects of Performance Contract on Organization Performance. The case of Ministry of Education Kenya. International Journal of Management and Business Studies. 2 29-37.

Luthans, F. (2011). Organizational behavior. New York, NY: Mc GrawHill.

Makewa, M. Rose \& Were Susan, (2017), Influence of Performance Contracting on Organizational Performance of Public Universities in Kenya. International Journal of Innovative Development \& Policy Studies.

Mauya, E. N. (2015). The importance of setting performance targets on service delivery in performance contracting at the ministry of tourism, Kenya. Global Journal of Human Resource Management. 3(5), 1-8.

Mbuthia R. N., Ngeri, B., \& Mwangi, B. (2012). Effectiveness of Performance Contracting in Public Institutions. International Journal of Science and Research.

Mutahaba, G. (2011). Report on adoption and use of performance management systems including performance measurement, monitoring, and evaluation in Africa.
Ndung'u, M. N. (2009). Performance management and contracting: Kenyan perspective, Jitegemea Press, Nairobi Kenya.

Newstrom, J. W. (2011). Organizational behavior $\left(13^{\text {th }}\right.$ ed.). New York, NY: Mc Graw Hill.

Nganyi, J. E., Shigogodi, J. M. \& Owamo, A. (2014). The Effectiveness of Performance Contracting in Service Delivery in Public Universities in Kenya. International Journal of Academic Research in Business and Social Sciences. 4(10), 413-441, October.

Ngetich, G. K. (2013). An investigation on the effects of performance contracting on service delivery. A Case study of the Nakuru Sub County. International Journal of Science and Research. 4, 1-7.

Obong'o, S. O. (2009). Implementation of performance contracting in Kenya. Retrieved from http://www.ipmr.net

Omondi, J. D. (2015). A Study on Effects of Performance Contracting Implementation on Service Delivery at Kenya Ports Authority. International Journal of Scientific Research.4(6).

Owino, A. (2014). The Effectiveness of Performance Contracting in Service Delivery in Public Universities in Kenya. International journal of Academic Research in Business and Social Sciences. 4, 1-7.

Wagana, D. M. (2015). Analysis of the relationship between devolved governance, political decentralization, and service delivery. European Scientific Journal. ESJ, 11.

Uusikyla, P., \& Virtanen, P. (1999). Public Sector Performance Contracting in Finland Public Management Department, Finnish Ministry of Finance.

Yukl, G. A., \& Latham, G. P. (1978). Interrelationship among employee participation, individual differences, goal difficulty, goal acceptance, goal instrumentality, and performance Personnel psychology. 